\title{
The Environment of Professional Activity for the Key Knowledge Workers
}

\author{
Mieczysław Morawski \\ Warsaw University of Technology, Warsaw, Poland, Email mieczyslaw.morawski@pw.edu.pl
}

\begin{abstract}
There is an extensive research gap in the study of methods participation and involvement key knowledge workers in different management processes. There are not many ideas how to manage knowledge workers, and in particular key knowledge workers (KKWs). KKWs - top class specialists, knowledge which they have acquired is not only advanced, but also an innovative and unique one and therefore it is always of highly individual nature. The best specialists (such as KKWs) have right to expect the special treatment adequate to the achieved results and represented potential. The knowledge-oriented enterprise have to create the adequate working environment for the KKWs. The comfort's zones for the specialists guarantee that they become aware investors of their own intellectual capital. Their engagement is the key issue regarding to the achieving the competitive advantage on the market which is based on the intangible assets. The article has a theoretical character referring to previously conducted by the author of the research. The aim of this paper is develop a model of KKWs' environment of professional activity within intelligent organization. The study was finalised with conclusions and the list of references. One of the conclusions: The elements of work environment which stimulate creativity are mainly represented by the so-called "soft management" components referring to various aspects of human capital management in an organization. However, these findings need to be interpreted with caution due to present limitations. Further research is necessary that would replicate and extend current study to other questions.
\end{abstract}

KEYWORDS: Knowledge Workers, management of Knowledge Workers, environment of professional activity for Key Knowledge Workers

\section{Introduction}

There is an extensive research gap in the study of methods participation and involvement ey knowledge workers in different management processes. There are not many ideas how to manage knowledge workers, and in particular key knowledge workers (KKWs). KKWs - top class specialists, knowledge which they have acquired is not only advanced, but also an innovative and unique one and therefore it is always of highly individual nature. The best specialists (such as KKWs) have right to expect the special treatment adequate to the achieved results and represented potential. The success of any organization is dependent on several factors among which human capital plays the crucial role. Knowledge workers are often the core of contemporary organization. It can be their ideas, experiences, interpretations, observations and reviews that keep the business moving forward. They invent new products, technologies and processes, but also analyze, develop and design more competitive business models, company strategies, costumer approaches, etc.

Creating a model of management knowledge workers, we need to solve many problems. It's necessary to answer such questions, for example:

- What does this mean for the managers and leaders of these workers?

- How to get, keep and what to offer KKWs who know more than others and can easily find an even better job?

- What are the elements to build a space to mobilize the intellectual activity, creativity and commitment?

- Which characteristics are desirable in the environment of KKWs to encourage their creative thinking and operating?

- How enforce and evaluate the effects of tasks performed when managers are not the experts and don't know of all the consequences of the adopted and approved solutions?

- How do measure the amount of knowledge a person creates or uses?

This type of work is mostly intangible - and very often invisible. It's difficult to determine the value of mental work and the ideas they inspire. 
The article gives the theoretical background of the term knowledge worker and covers the part of the author's research on knowledge workers.

The aim of this paper is develop a model of the environment of professional activity for the Key Knowledge Workers. The author of the following study conducts research focussing on the knowledge worker, managing this group of employees, motivating them, working in a group and intellectual leadership for a decade. During this time, he conducted a lot of research, based on surveys and interviews.

The survey questions were addressed not only to entrepreneurs and managers. In fact, in each study, personal interviews were conducted with key employees. The obtained results were used in presenting final conclusions.

\section{Knowledge workers - definitions and observations in the literature of the subject}

Highly gifted people represent the core of new economy, e.g.: ICT specialists, engineer, fashion designers, architects, consultants and many other professions. Their activities are based on creativity and high competences. In the literature of management science are often called "knowledge workers". Although importance of knowledge workers has been widely discussed in many earlier studies globally, yet, so little is really known about these workers. and It is still difficult for many people to understand on exactly what this term means. In recent years the dominance of knowledge economies has resulted in a need for knowledge workers who are adept at intellectual thinking, managing of knowledge and problem-solving at work. Knowledge workers are workers whose main capital is knowledge.

The term of a "knowledge worker" is included among the concepts which characterize different categories and groups of employees distinguished among other members of an organization by the much higher level of education, knowledge, skills, experience, talent and other abilities and predispositions. We've come a long way since management expert Peter Drucker first created the term "knowledge worker" in the late 1950s. In fact, Drucker was referring to a set of workers that were not making things with their hands, but creating ideas using their minds. Drucker defined knowledge worker as: "someone who knows more about his or her job than anyone else in the organization"'(Maruta, 2011, 35-47). According to Drucker, knowledge worker is a term used to identify a group of workers who own the means of production their knowledge (Wickramasinghe \& Ginzberg 2001). At that time, they began to be seen a change from manual labor to jobs that need high levels of expertise, education, and experience. Now as estimated, anywhere from 25-50 percent of jobs require people to create, use, and share knowledge. According to T.H. Davenport, knowledge workers possess a high level of professional knowledge, education or experience, and creation, transfer and practical use of knowledge are among the core tasks of their work (Davenport 2005, 21-24) In other words, Davenport defines knowledge workers as some people who are highly expert, educated and experienced; their main goal is to create, distribute and use knowledge. Knowledge worker is a member of organization who utilizes knowledge to increase the productivity Davenport claims that the primary purpose of a knowledge workers' job involves the creation, distribution, or application of knowledge. Knowledge workers think for a living. As businesses increase their dependence on information technology, the number of fields in which knowledge workers must operate has expanded dramatically (Cooper 2006).

In turn, Davis and Parker (1997) argue that the work based on knowledge is a human mental work performed in order to generate useful information. During this work knowledge workers find information, using the knowledge involved mental models, using concentration and attention.

Due to tacit knowledge, knowledge as a whole remains intangible. The intangibility of knowledge makes knowledge workers special and difficult to manage. The most important part of work performed by knowledge workers happens in their heads, even though the final result may be material (Mladkova 2013, 446). Knowledge workers are highly regarded by employers for their innovation and creativity. Thompson defined knowledge worker as "workers who possess thinking skills and change symbols and ideas when they identify and solve problems". Due to the intangible character of knowledge, managing knowledge workers requires different approaches, tools and methods than managing non-knowledge workers (Thompson et al. 2001, 923-42). Knowledge 
workers are employees who are responsible for knowledge work, and in a near future the majority of work force will be constituted of this group of workers. For many organizations, knowledge workers are the most important employees and it is critical for organizations to retain them. Human Resources Management can increase work efficiency of employees by increasing the level of job factors. Improving the job factors provides conditions demanded by knowledge workers and improve their efficiency as well as satisfaction, involvement and loyalty.

Knowledge workers are usually responsible for exploring and creating ideas, rather than implementing and managing existing processes. New technologies, new products, new designs, new models for doing business - these are typical outputs of knowledge work.

In a broader sense, in the conditions of knowledge-based economy (KBE) these workers create knowledge (or are potentially ready for it) based on the available information. Mladkova states that knowledge workers represent the special group of highly qualified employees. The specificity of their work and management reflect the intangibility of their major tool and resource, i.e. knowledge. Owing to tacit knowledge, the entire knowledge remains intangible. The intangibility of knowledge makes knowledge workers special and difficult to manage. The most important part of work performed by knowledge workers happens in their heads, even though the final result may be material (Mladkova 2013). Most valuable employees are those that can grow and learn together in line with the business change and transformations.

\section{Empirical Research - The most important findings}

One of the significant results of the author's studies (Morawski 2016; Morawski, Szałko 2015; Morawski 2014) was to determine a set of characteristic features of a Key Knowledge Worker defining his/her competences, organizational roles, motivations, etc. (see table1).

Table 1. Features of Key Knowledge Workers

\begin{tabular}{|c|c|}
\hline Features/ categories & Key Knowledge Worker \\
\hline Substantive competencies & $\begin{array}{l}\text { unique, top quality knowledge based on many } \\
\text { years of experience and master skills }\end{array}$ \\
\hline Other valuable competencies & $\begin{array}{l}\text { leadership skills, extensive contacts in the sector } \\
\text { (with suppliers, clients, scientists, investors), } \\
\text { innovative approach, mentoring skills }\end{array}$ \\
\hline Substitution for a leaving employee & $\begin{array}{l}\text { practically impossible, requires the introduction } \\
\text { of long-lasting programmes for the succession } \\
\text { of posts and trainings of successors }\end{array}$ \\
\hline $\begin{array}{l}\text { Organizational roles: performed in the same time } \\
\text { or different time }\end{array}$ & $\begin{array}{ll}\text { - } & \text { top level manager } \\
\text { - } & \text { management representative } \\
\text { innovator and the author of } \\
\text { - } & \text { patents } \\
\text { coordinator and leader of } \\
\text { - } & \text { many projects } \\
\text { - } & \text { internor } \\
\text { - } & \text { supervisor of newly } \\
\text { admitted employees }\end{array}$ \\
\hline Incentives & $\begin{array}{ll}- & \text { individually agreed salary } \\
\text { - } & \text { extensive financial means } \\
\text { - } & \text { for trainings } \\
\text { contracts for participation in } \\
\text { - company profits } \\
\text { comfortable work conditions } \\
\text { adjusted to individual } \\
\text { preferences } \\
\text { - } & \text { flexible working hours } \\
\text { - } & \text { autonomy at work }\end{array}$ \\
\hline
\end{tabular}




\begin{tabular}{|l|ll|}
\hline Accomplished career level & $\begin{array}{l}\text { professional comprehensive } \\
\text { qualifications } \\
\text { authority of knowledge } \\
\text { recognition and fame outside } \\
\text { the company }\end{array}$ \\
\hline Fundamental work results & $\begin{array}{l}\text { initiating changes based on } \\
\text { creative thinking } \\
\text { implementation of systemic } \\
\text { management concepts } \\
\text { establishment of new } \\
\text { products generations }\end{array}$ \\
\hline
\end{tabular}

Source: own study

Other findings resulting from the research:

1. The Key KWS are the top class specialist constructing the intellectual and substantive elite. They constitute the group of knowledge workers who have decisive influence on the value of core corporation competencies. They provide unique skills, extensive professional contacts, deep and broad experience. Knowledge which they have acquired is not only advanced, but also an innovative and unique one and therefore it is always of highly individual nature (so-called: tacit knowledge). They include specialist within enterprises, for example: high-class engineers, technologists, programmers, economists and experienced managers.

2. The Key KWs have the right to expect special working conditions. The best specialists have right to expect the special treatment adequate to the achieved results and represented potential. If enterprise treats these persons in the same way as the others - especially these who are judged as the worst, it can count with negative consequences.

3. The Key KWs expect organizational comfort which provide them with extensive independence and opportunities for professional skills advancement. They also value organizational culture in which competencies and knowledge are respected.

4. You need an approach that can be called management without management. Managing Key KWs can be a difficult task. Most of them prefer high level of autonomy, and do not like being overseen or managed. Projects must be carefully considered before assigning to a key knowledge worker, as their interest and goals will affect the quality of the completed project. Solutions to empower the best employees are needed. Specific solutions: high level of autonomy, various work hours, motivation referring to the content of work, personal responsibility, opportunities for continuous development and learning. Key KWs must be treated as unique people like artists in their profession.

\section{Conclusions}

The conclusions resulting from the carried out research allowed formulating the proposals for basic guidelines related to the construction of a comprehensive knowledge workers' management system, which may become useful for enterprises and their managers. These guidelines relate to e.g. the needs for identifying the core values of an enterprise, defining its mission, vision and strategic goals, developing the key competences of the intelligent organization, attracting and identifying key knowledge employees, developing the personnel strategy for knowledge workers. It is necessary to specify, at the strategic level of an enterprise management, the substantive guidelines for KKWs management system construction.

The underlying guidelines are as follows:

1. The identification of basic values featuring a professional company and ingrained in the concept of an intelligent organization. Professionalism is of fundamental importance as the basic imperative influencing attitudes presented towards supervisors and co-workers and manifesting itself in competent, rational, thought over and logical activities.

2. The identification of a vision, mission and strategic goals focused on competitive advantage construction based on intellectual capital quality. Its consequence is shown in the form of emphasis placed on attracting, developing and retaining best personnel in the company. 
3. Defining key competencies in an organization which ensure its competitive position at a given market. It refers to certain unique skills which allow an enterprise for added value creation, as perceived by its clients, which outweighs advantages offered by market competitors.

4. Distinguishing key knowledge workers. It has to be clearly specified which employees and at which positions represent competencies which are in what respect crucial for an enterprise competitive position construction (e.g. unique education, intellectual predispositions for creative performance, entrepreneurial attitudes and behaviour, extensive business contacts).

5. Individual strategy preparation for KKWs. The most important choices to make: signing agreements which guarantee employment stabilization and opportunities for professional development, providing comfortable working conditions, offering capital partnership.

Particular solutions referring to key employees can follow the suggestions presented below:

- Career based on work positions rotation, changing organizational roles, performing different, changing in time and scope functions for an organization, taking part in different projects.

- Promotion depending on sharing one's own experiences with others: playing the role of an internal coach, mentor, trainings, seminars and conferences organizer, participation in trainings upgrading knowledge sharing skills.

- Social competencies development by organizing knowledge sharing places: workshops for particular departments, meetings with new employees, inviting key and less experienced employees to work together in the same team.

- Organizational culture creation based on the sense of creating a cooperating community underlying collective responsibility principles: organizing events for particular occasions gatherings of all company employees, joint celebrations of both the company and individual employees success, motivation oriented business trips, meetings with families, etc. competitions checking knowledge about the company, online discussion forums, company newsletter publishing. Emphasis on meeting and the participation of all company employees in them, the sense of closeness and direct communication.

- Company environment monitoring by means of formal relations (personal consultancy agencies, universities, research and development institutes) and informal ones (distinctive scientists, patent authors, inventors, professional experts) in order to attract the best candidates from the environment.

- Ongoing monitoring and development of company employees presenting the highest potential and performance by applying talent management or leader creation programs by the establishment of suggestions offering systems.

- Flexible selection of human resources management methods divided into the leading and supportive ones, depending on the preferred development directions and company expansion. The situation may prefer new knowledge creation methods (technologies, products), the existing solutions implementation in new applications, gaining knowledge from external sources, concentrating knowledge in teams, sharing knowledge between functional areas, etc.

- Constructing tools for the purposes of knowledge intensification and dissemination in an enterprise: information techniques, access to data bases or the topography of office rooms.

The presented set of guidelines, if implemented in the company, allows for the creation of an environment of key employees for professional activity. The basic areas and highlighted specific factors that it covers are based on the author's research and his analytical considerations. Elements of the work environment that stimulate a high level of substantive and intellectual activity of knowledge workers are mainly represented by the so-called "soft management" components relating to various aspects of human capital management in the organization. Their coexistence must be properly targeted at 
empowering employees. Knowledge workers are employees whose major tool and resource is knowledge. Managers cannot follow processes of knowledge work and therefore they cannot control knowledge worker while working. It may be difficult to identify and support the most productive moment of a knowledge worker's activity, and to control it. We need management by encouragement based on trust, mutual communication, versatile motivation, job satisfaction, cooperation, democratic styles of leadership.

\section{References}

Cooper, D. 2006. "Knowledge Workers.” Canadian Business. 79 (20).

Davenport, T. 2005. Thinking for a Living: How to Get Better Performances and Results from Knowledge Workers. Boston: Harvard Business School Press.

Davis, G. B., Parker C. A. 1997. “Systematic approach.” PhD diss. New York: Barron's Educational Series.

Maruta, R. 2011. "Transforming knowledge workers into innovation workers to improve corporate productivity." Knowledge-Based Systems 30: 35-47.

Mladkova, L. 2013. "Knowledge Worker from the Perspective of Their Manager." In Proceedings of the 14th European

Conference on Knowledge Management, edited by Janiunaite B., Petraite M., 446. Kaunas: Kaunas University of Technology.

Morawski, M. 2016. "How to Manage Knowledge Workers in Creative Industries. Evidence from Poland Polish National Knowledge Management Styles. Studies in selected companies representing creative industries." In Proceedings of the 17th European Conference on Knowledge Management 639-649. Belfast: Ulster University.

Morawski, M., Szałko B. 2015. "The Process of Creativity in the Light of the Research Based on the 'Icedip' Model in the Selected Organizations of Creative Industries.” In Business and nonprofit organizations facing increased competition and growing customers' demands, edited by A. Nalepka, A. Ujwary-Gil, 53-66. Nowy Sącz: Wyższa Szkoła Biznesu - National-Louis University, Vol. 14.

Morawski, M. 2014. "Polish National Knowledge Management Styles. Studies in selected companies representing creative industries." In Proceedings of the 15th European Conference on Knowledge Management, edited by Vivas C. and Sequeira P, 708-715. Santarem: Polytechnic Institute of Santarem.

Thompson, P., Warhurst, C., Callaghan, G. 2001. "Ignorant theory and knowledgeable workers: interrogating for connections between knowledge, skills and services.” Journal of Management Studies 38(7): 923-42.

Wickramasinghe, N., Ginzberg, M. 2001. "Integrating knowledge workers and the organization: the role of IT." International Journal of Health Care Quality Assurance 14(6): 245-53. 